Volume 3, Issue 4, Year 2019, pp. 329-354

E - ISSN: 2587-3008

URL: http://ratingacademy.com.tr/ojs/index.php/jsp

DOİ: https://doi.org/10.26900/jsp.3.034

Research Article

\title{
PRESERVING THE SPATIAL MEMORY IN HISTORIC BUILDINGS AND SPACES AND ITS CONTRIBUTION TO THE URBAN IDENTITY: A CASE STUDY OF ÇANAKKALE URBAN SITE ${ }^{1}$
}

\author{
Kübra YANMAZ * \& A. Esra CENGIZ ** \\ * Çanakkale Onsekiz Mart University, Graduate School of Natural and Applied Sciences, Department \\ of Landscape Architecture, TURKEY, e-mail: kubrayanmaz17@gmail.com \\ ORCID ID: \\ ** Assist. Prof. Dr., Çanakkale Onsekiz Mart University, Faculty of Architecture and Design, \\ Department of Landscape Architecture, TURKEY, e-mail: aesraozel@ hotmail.com \\ ORCID ID: https://orcid.org/0000-0001-6238-970X
}

Received: 04 September 2019; Accepted: 20 September 2019

\section{ABSTRACT}

In the present study, it is aimed to preserve the place of historic buildings and spaces in the spatial memory together with their images and to investigate its contributions to the urban identity. In this context, an examination was made on eight historic buildings and spaces selected from Çanakkale Urban Site (an avenue, a street, a square, a garden, a courtyard, a religious building, an education building, and a registered old building). Within the scope of this study, a specialist group of 70 people was determined in the survey technique. The aim of the survey technique was to question the spatial memory, urban image, and urban identity cases and their relations with each other through the examples selected from Çanakkale Urban Site.

In this context, when the buildings and spaces which have acquired a place in the urban memory are defined in terms of spatial memory parameters and urban images, this also strengthens their contributions to the urban identity. The buildings and spaces selected as the material in the study are still being used, which strengthens the spatial memory parameters. The spatial memory parameters which affect the places of the buildings and spaces concerned in the urban identity the most are the parameters of "historical and cultural value", "memory value and continuity of use", "originality and rarity value", and "aesthetic and artistic value", respectively. The historic buildings and spaces identified with all these parameters contribute to the city's states as a city of "history", "culture-art", and "tourism" the most. When the buildings and spaces concerned are evaluated in terms of the urban images, they are mostly identified as "districts", "nodes", "paths", and "landmarks", which strengthens their places in the urban identity.

As a result of the study, proposals were made for the preservation of the spatial memory parameters in historic buildings and spaces and for the continuity of the historic buildings and spaces by emphasizing the contribution to the formation of the urban image and the urban identity.

Keywords: Çanakkale Urban Site, Spatial Memory, Spatial Memory Parameters, Urban Identity, Urban Image, Conservation. 


\section{INTRODUCTION}

Cities are social, political, economic, and cultural areas of interaction besides being physical spaces that enable people to coexist and that provide the labor force (Wirth, 2002) and they are gradually standing out in the globalized world (Güler et al., 2016). A city becomes a physical, social, political, and cultural area when the accumulations belonging to different periods and ways of life of history gather (Birol, 2007). Therefore, neither the coexistence of buildings nor the physical plans drawn by the experts who organize the development of a city is enough for the formation of a city. A city is at the same time a social phenomenon and one should first of all take this into consideration in order to read the traces of architecture in the city accurately (Kuban, 2016). Likewise, Calvino (2002) expresses that "cities, like dreams, are made up of desires and fears". Expectations and concerns also shape the living spaces. For instance, in those societies where war was experienced, the cities were enclosed with ramparts and shaped with a planning understanding towards protecting it and those in it.

On the other hand, cities are spaces where societies and individuals coexist and socialize; which are built by thousands of different people with very different characteristics from any sociocultural classes and different ethnic groups; which assume the role of being a meeting place for different sections of the society (Erdönmez and Ak1, 2005; Farrelly, 2011); and where events take place and life flows (Farrelly, 2011). With their social and cultural assets besides their spatial importance, cities have an original urban identity and are distinguished from each other so (Güler et al., 2016). Thus, the concepts of city and space cannot be considered separate from each other and spaces make a great contribution to the physical-social formation of a city.

There is also a relationship between a space and a user that is nourished by interaction. A human being is a living thing with physical and spiritual needs. While expecting a space to meet his/her needs, he/she also wants it to be good for his/her soul (Yıldırım Erniş, 2012). In addition, space, time and motion determine the boundary of a city and a city holds on to some time on the space. Thus, the spaces where city dwellers pass their time and the times passed in these spaces make a cultural contribution to a city and also define the ways of life of city dwellers (Kaypak, 2010).

A space is the most important element which forms the basis for an environment built by people; which has not been identified with definite limits; and which develops in line with past experiences and accumulations. While examining the continuity of spaces, the permanence of those assets of theirs which influence the entire society is also scrutinized (Turgay, 2013). In this context, spatial memory is defined as "the recording of space-related learning, sensations, experiences, perceptions, and memories in the memory during life with not only their own components but also the phenomena taking place in it, the ambient characteristics, and life, in other words, with 'its context' and their association" by Öymen Özak (2008).

The functioning of the short- and long-term memories is essential in giving meaning to a space and in the formation of the image of that space. The images a person has acquired through his/her past experiences are kept in the long-term memory (Turgay, 2013). This relationship between an image and the physical form creates the spatial perception and the urban image assumes the most important role in the formation of the urban identity (Lynch, 2014). Spaces either are preserved or cannot be preserved in users' memories. Each remembered space takes its place in the memory together with its respective image. Urban images also draw attention as important reference points while defining the place of a city in the spatial memory.

The urban memory results from the coexistence of "space, time, memory, and identity". The processes of formation of the identity and the memory and ensuring/preserving their continuity over time play significant roles in such issues as the spatial perceptions by the 
individuals living in cities, their sense of belonging, and their lifestyles (Aslan and Kiper, 2016). The elements which make up the urban identity can be evaluated in terms of the elements caused by the natural, human, and man-made environments (Önem and Kilınçaslan, 2005). The urban identity takes form within a long time span. It shapes the city as a blend of its such qualities as its geographical content, cultural level, architecture, local traditions, and lifestyle (Suher et al., 2004). For the formation of an urban identity, the continuity of these assets should be provided and the material and immaterial assets which convey the messages coming from the past of the city to the future should be conserved. Therefore, one of the most important features which reflect the urban identity is the historical and architectural features of that city and their ways of preservation in the spatial memory (Ayyıldiz and Ertürk, 2017). Indeed, the identity of a city which has experienced the surprising periods of economic, cultural, and political history is made up of the visual pieces of evidence of the past that have permanently acquired a place in its spatial memory (Lynch, 2014).

In summary, what distinguishes urban spaces from each other and makes each of them different from another is the events experienced by their society and the traces they have left regarding them. Trailing a society in the space that it belongs to is only possible through the survival of the buildings and spaces that it left behind and transferred its life experiences on up to the present time. These buildings and spaces, the most important witnesses to the societies living in the past, acquire historical value and form a permanent spatial perception in the memories of the city and of city dwellers when they reach the present time.

In the study carried out in this context, the eight historic buildings and spaces selected as examples from Çanakkale Urban Site were evaluated in terms of spatial memory parameters, urban identity, and urban images and proposals were made concerning this.

\section{MATERIAL AND METHOD}

\subsection{Material}

Çanakkale has significant potential with its location on the coast of the Dardanelles as well as with its rich archaeological and cultural wealth, slightly degraded nature, and climatic diversity (Koç, 2004). According to the population census data of 2018, the population of the central district is 136.002 people (TurkStat, 2018). In the resolution by the Council for the Conservation of Cultural and Natural Properties of Edirne (EKTVKK), dated 26.05.1995, it was decided to register the region between Sarıçay and Calvert Park (Public Garden) and the sea and Atatürk Avenue as "Çanakkale Urban Site" (Figure 1) (Directorate of the Regional Council for the Conservation of Cultural Properties of Çanakkale-ÇKVKBK, 2018). The eight historic buildings and spaces (an avenue, a street, a square, a garden, a courtyard, a religious space, an educational building, and an example of civil architecture) located within Çanakkale Urban Site and selected in line with the purpose of the study define the main material of the study (Figure 2). Such visual and literary data as the reports, maps, photographs, plans, and sketches obtained from the relevant public institutions and organizations as well as the photographs taken and observations made in the study area were each evaluated as a supplementary material within the scope of the study. 
Figure 1. The location of the study area in Turkey and in Çanakkale province (created by making use of Turkey ShapeFile, 2019 and the Directorate of the Council for the Conservation of Cultural and Natural Properties of Çanakkale-ÇKTVKK, 1996)

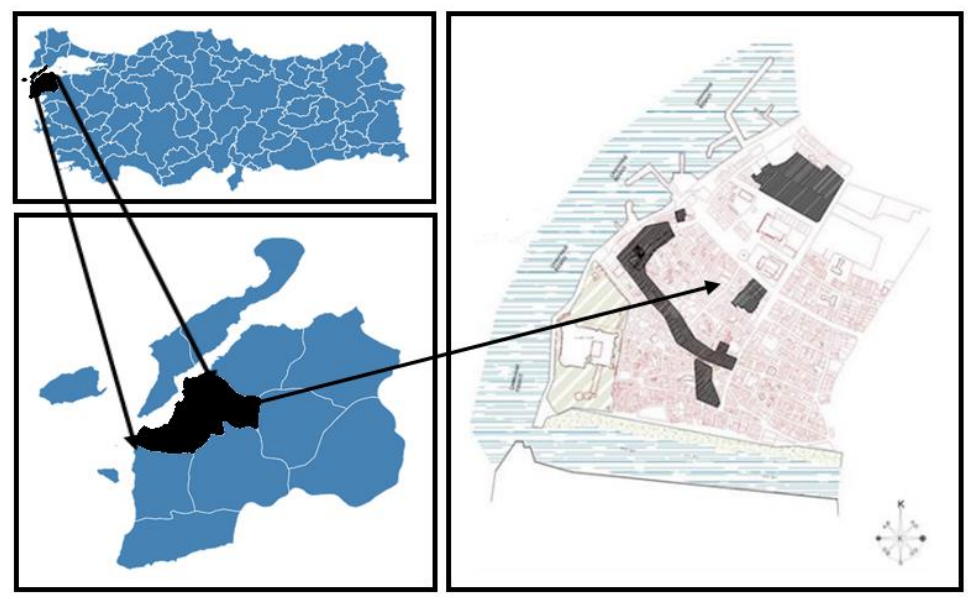

\subsection{Method}

The survey technique was employed in the study in order to question the place of the selected historic buildings and spaces in the spatial memory of the city and to determine their contributions to the urban identity. Moreover, the buildings and spaces concerned were addressed according to Lynch (2014), who determined the formation of an urban image in five different physical elements; which of these elements the buildings and spaces concerned corresponded to was determined; and what kind of a contribution they made to the urban identity of Çanakkale was established. The sample size of the survey study was created with the non-probability and purposive sample techniques and a specialist group of 70 people was determined. This specialist group was selected from the people who lived in Çanakkale for long years, who were responsible for the physical structure of the city, and who took part in the social responsibility projects for the city. People from the employees in the Directorate for Development and Urbanization of Çanakkale Municipality, the Special Provincial Administration of Çanakkale, Çanakkale Archaeology Museum, and the Provincial Directorate for Environment and Urbanization in Çanakkale (e.g. architects, city planners, archaeologists, and engineers) as well as from the academics and the city intellectuals were included in the specialist group.

The survey in the study by Taşçığlu and Altunkasa (2018) was taken as the basis when drawing up the survey; however, the different survey examples in various theses and papers on the subject of the study (Topçu, 2011; Asar, 2013; Başaran Uysal, 2013; Er, 2014; Bozdağ, 2015; Kürkçüoğlu and Ocakçı, 2015; Altuğ Turan and Gülgün, 2016; Diker and Çolpan Erkan, 2017; Güneroğlu and Bekar, 2017; Turan and Yalçıner Ercoşkun, 2017) were also examined and an original survey was drawn up in line with the subject and purpose of the study. The survey consisted of two sections. The first section contained questions to categorize the respondents, whereas the respondents were shown photographs (Figure 2) of the selected historic buildings and spaces in the second section. The spatial memory parameters of the historic buildings and spaces in the photographs, their contributions to the urban identity and which urban image(s) they corresponded to were questioned. The 5-point Likert scale was utilized to quantify the spatial memory parameters of the buildings and spaces concerned and their contributions to the urban identity and the results were evaluated in SPSS 24.0 program. Besides the statistical results of the survey, the oral $\&$ written expressions of the respondents were also used in the evaluations made. 


\section{A SHORT HISTORY OF THE HISTORIC BUILDINGS AND SPACES SELECTED}

The urban image classes by Lynch (2014) were utilized when selecting the historic buildings and spaces which constituted the main material of the study. Lynch (2014) defined the urban image within the physical elements as paths, edges, districts, nodes, and landmarks. Thus, as a result of the observations and examinations within Çanakkale Urban Site, the historic buildings and spaces where the physical elements could be taken into consideration were examined as examples. The examples selected in this context were Çarşı Avenue, Fetvane Street, Zafer Square, the Public Garden, Yalı Khan, the Yalı Mosque, the Stone School (Taş Mektep)/the Guest House for Teachers, and the House of Emilie Vitalis/the Continuing Education Center of ÇOMU. The buildings and spaces concerned (Figure 2) were also preferred as they acquired a place in the urban memory but did not stand out much, along with their original historical qualities. Some of the buildings and spaces concerned have survived up to the present time as the representatives of a specific period in the urban memory, with some of them maintaining their original function but some of them undergoing change in function.

Figure 2. The historic buildings and spaces selected in the study area (created by making use of the Directorate of the Council for the Conservation of Cultural and Natural Properties of Çanakkale-ÇKTVKK, 1996)

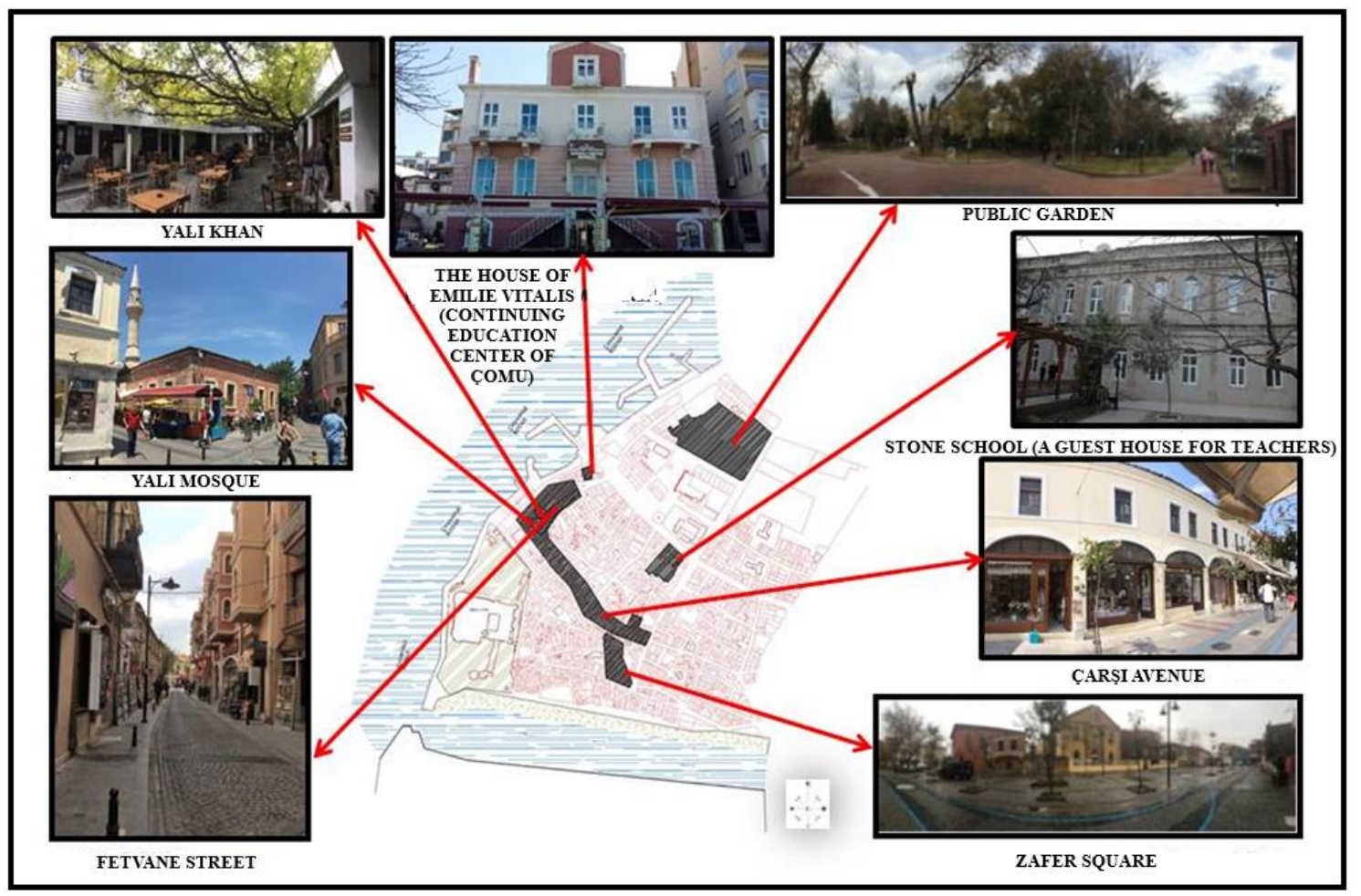

Çarşı Avenue: Commercial life and shops are known to be concentrated along Yalı and Çarşı Avenues in the architectural pattern of Çanakkale (CHVIP-the Historic City Commission, 2016). Especially Çarş1 Avenue stood out as a place where the function of trade developed in those periods when the city was established. Upon the establishment of the city in the 14th century, shops began to form for the necessary requirements of the public in this region, which was close to the quay. It is known that the tradesmen in the place concerned generally comprised Muslims, Greeks, Armenians, and Jews (Büberci, 2003). The avenue is intensively maintaining its commercial function today as well. According to the report by the CHVIP-the Historic City Commission (1997), Yalı Avenue, Fetvane Street, Çarşı Avenue, Fatih Mosque Square and Zafer Square as well as the streets leading to these two squares are at the same time spaces where the urban silhouette is good. 
Aynalı (Mirrored) Bazaar is located at Çarşı Avenue and has a significant place in the urban memory of Çanakkale and İlya Halyo from the Jewish community had it constructed in 1890 (Eren, 1990). Containing souvenir shops, this bazaar was used as a shopping arcadebazaar during the early periods of its construction but as a stable by the English soldiers as it was burnt and collapsed during Çanakkale Wars. Repaired in 1967, the bazaar was reintroduced into the city by Çanakkale Municipality with the restoration project drawn in 2004 by Architect and Archaeologist Prof. Dr. Ümit Muzaffer Serdaroğlu (Güleryüz, 2017).

Fetvane Street: Fetvane Street is located between two historic spaces (Muvakkithane [timing room] and the Clock Tower) which announce time in the city (Uralman, 2012). The governor of the city had the Clock Tower constructed in 1897 with the money donated by an Italian named Vitalis, who worked as a consul in Çanakkale for long years. The muvakkithane (timing room) is a two-storey masonry building. The building, the downstairs of which was a shop and the upstairs of which was a muvakkithane, was constructed in 1867, according to its inscription (Kurtman, 1991). Fetvane Street runs perpendicularly to Çarş1 Avenue and to the west of it are the City Museum and the Yalı Mosque. Fetvane Street has generally not changed its function since the early dates of its formation. This street, where Greek taverns and depots were generally available initially, also includes buildings which are used as shops, restaurantscafés, and hotels today besides the spaces for entertainment purposes.

Zafer Square: An Armenian community that arrived in the city in the 1650s created a neighborhood in the Zafer Square (the Old Church) region (Çavuş and Koç, 2004). The Armenian Church constructed in 1873 is located at Zafer Square (Başaran Uysal, 2013). The church was built with hewn stones and preserves its originality as an architectural character (CHVIP-Historic City Commission, 1997). The Fatih Mosque, another important building in the area, is located at the northern endpoint of the area. This mosque was constructed in 1462 and completely renovated between 1862 and 1863 in the reign of Sultan Abdülaziz (Koç, 2006). Apart from it, the Armenian Primary School, the Tifl Mosque and the Building of Nedime Hanım are located at and around Zafer Square (Başaran Uysal, 2013) and these buildings form a periphery around the square. The Armenian Church, one of the most striking buildings at the square, is now mostly used by the Faculty of Fine Arts of Çanakkale Onsekiz Mart University (ÇOMU). Even though the historic buildings located at and around Zafer Square preserve their own original identities in the general sense (CHVIP-Historic City Commission, 1997), it is seen that many of them have lost their original function today.

The Public Garden: The garden of the mansion located on the side of the strait and owned by the Calvert Family that lived in Çanakkale in the 1840s makes up some of the current Public Garden. Spreading over a vast area, this garden was designed to qualify as an English garden (Allen, 1999; from Erduran Nemutlu et al., 2008). Discovered to house 85 ornamental plants, the Public Garden (Erduran Nemutlu et al., 2008) is an important space which also stands out with its landscape value within the urban site (CHVIP-Historic City Commission, 1997).

Yalı Khan: Yalı Khan, whose date of construction is written as 1889 on the signboard suspended in it, had not changed its initial function and had been used as an accommodation building until the late 1970s (Tolun, 2013). It is mentioned that Yalı Khan, which is known to have functioned as a hotel where those who arrived in Çanakkale to work stayed in the early years of its construction, had a larger, cleaner, and wider courtyard than those of the other khans in Çanakkale and contained a large number of rooms lined up around the courtyard (Algör, 2007). Yalı Khan, which has two gates that lead to Yalı Avenue and Fetvane Street and which houses bookshops, handicraft workshops, and cafés today, is also like a crossing corridor which joins both streets together. 
The Yall Mosque: Although it is known that the first construction of the Yalı Mosque belonged to the early 18th century (Dündar, 2017), the Yalı Mosque and the shops were damaged in the fire that broke out on 6 August 1836 and Tavil Ahmet Ağa had it constructed again. On the other hand, the fire that broke out on 27 January 1854 completely burned the mosque too (Korkmaz, 2010). According to what is written on its inscription, the mosque was last renovated in 1854 following the fires it had suffered from (Dündar, 2017). The fenced graveyard of the mosque renovated by Colonel Halil Bey houses the tomb of Colonel Halil Bey (Eren, 1990). This locality, where Yalı Khan, the Yalı Mosque and Yalı Public Bath are located, is also one of the early cores of the city (Algör, 2007).

The Stone School (Taş Mektep) (A Guest House for Teachers): The school building constructed depending on the modernization initiatives in the Ottoman Period is known to have been the building of "Kale-i Sultaniye Mekteb-i İdadî", which was constructed using the state budget in 1892. Known as "Taş Mektep", this school building is two-storeyed (Uygun, 2015). The school, which took the name "Çanakkale Sultanisi (high school)" in 1913, began to provide education at the high school level, but education was terminated during the First World War. Having begun to be used as a hospital after the city had begun to be controlled by the English following Çanakkale Wars, the Stone School later functioned as barracks (Eren, 1990). The building assumed the mission of being the only secondary school of the city between 1924 and 1949 and took the name "Çanakkale Lisesi (High School)" on 12 September 1949. The İdadî Building (secondary school) served as "the first teacher training school" between 1956 and 1971. Used as a Commercial High School between 1971 and 1998, this building was restored in 2000 and provided with the function of being a "Guest House-Hotel for Teachers" (Uygun, 2015).

The House of Emilie Vitalis (Continuing Education Center of ÇOMU): "Emilie Vitalis", an Italian merchant who lived in Çanakkale, had it constructed in the late 19th century. Belonging to Emilie Vitalis, who worked as the Italian Commercial Attaché and a merchant, this building was designed as both an office (official department) and a house (Tombul, 2015). According to the information in the land office, the building concerned was sold to the Treasury in 1937 by the daughters of Italian Consul Ezir Karalin (Algör, 2007). The building functioned as a house for a while in the early 20th century for Mrs. Milton - the director of English cemeteries. Used as the Directorate of TEKEL from the early years of the Republic to 1992, the building was allocated to Çanakkale Onsekiz Mart University in 1992 and used as the Rectorate Building until 2001 (Tombul, 2015; Algör, 2007). The building is still being used by the university and its upstairs serves as the Continuing Education Center of ÇOMU and its downstairs as a café.

\section{FINDINGS}

Such basic characteristics of the respondents as gender, age, marital status, educational status, occupation, participation in cultural, artistic, and environmental activities, and membership to a nongovernmental organization were questioned in the first section of the survey study. On the other hand, the questions in the second section of the survey were aimed at determining the selected historic buildings and spaces in terms of spatial memory parameters, urban identity, and urban image. The questions in this section were individually organized for each building and space.

The respondents were shown the photographs in Figure 2 and asked to evaluate the historic buildings and spaces concerned in terms of spatial memory parameters, urban image, and urban identity via their knowledge in their own memory together with these photographs. The spatial memory parameters and the urban identity were questioned with 5 assessment criteria and the 5-point Likert Scale (5-Very Good, 4-Good, 3-Slightly Good/Moderate, 2-Bad, 
1-Very Bad). Before that, the reliability degrees of the scales in the survey had been examined and Cronbach's alpha statistics had been used for this purpose. Whether the parameters quantified different views of the respondents was assessed with Hotelling's $\mathrm{T}^{2}$.

\section{1. Çarşı Avenue}

The avenue, which is still preserving the architectural structure of the period when it was first constructed, makes more contributions to the formation of the spatial memory in the context of the parameter of "historical and cultural value" (mean 4.26). This also has positive impacts on the urban identity and the space concerned contributes to the "historical" identity of the city in the first degree with the highest average (4.24\%). As also stated by the respondents, Çarşı Avenue is an avenue which has acquired a place in the memories of the city dwellers and of the incomers to the city in terms of "memory value and continuity of use" since the city was first established and this parameter makes the second highest (mean 4.11) contribution to the formation of the spatial memory. The local people and those coming from the surrounding settlements mostly use this avenue for shopping. The avenue is at the same time a triangulation and reference point used for meeting, assembling, and crossing. Çarşı Avenue is a space with "original" qualities since it reflects the architectural character of the period of its construction. Moreover, the rates, colors and forms of the masses are in harmony with each other along the line that makes up the silhouette of the avenue. This distinguishes the avenue from the other avenues and streets, thereby presenting an original structure (Table 1).

Table 1. Reliability of the scales (spatial memory/urban identity) for Çarşı Avenue and their mean values

\begin{tabular}{|c|c|c|c|c|c|c|c|c|c|}
\hline & Spatial Memory Parameters & Mean & \begin{tabular}{c|} 
Std. \\
Deviation
\end{tabular} & & $1^{*}$ & $2 *$ & $3 *$ & $4^{*}$ & $5^{*}$ \\
\hline \multirow{11}{*}{ 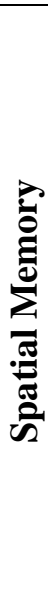 } & \multirow{2}{*}{ Historical and cultural value } & \multirow{2}{*}{4.26} & \multirow{2}{*}{.928} & $\mathrm{n}$ & 0 & 4 & 11 & 18 & 37 \\
\hline & & & & $\%$ & 0 & 5.7 & 15.7 & 25.7 & 52.9 \\
\hline & \multirow{2}{*}{ Originality and rarity value } & \multirow{2}{*}{3.73} & \multirow{2}{*}{.883} & $\mathrm{n}$ & 1 & 2 & 27 & 25 & 15 \\
\hline & & & & $\%$ & 1.4 & 2.9 & 38.6 & 35.7 & 21.4 \\
\hline & \multirow{2}{*}{ Aesthetic and artistic value } & \multirow{2}{*}{3.50} & \multirow{2}{*}{1.018} & $\mathrm{n}$ & 2 & 9 & 23 & 24 & 12 \\
\hline & & & & $\%$ & 2.9 & 12.9 & 32.9 & 34.3 & 17.1 \\
\hline & \multirow{2}{*}{ Memory value and continuity of use } & \multirow{2}{*}{4.11} & \multirow{2}{*}{1.136} & $\mathrm{n}$ & 3 & 4 & 11 & 16 & 36 \\
\hline & & & & $\%$ & 4.3 & 5.7 & 15.7 & 22.9 & 51.4 \\
\hline & \multirow{2}{*}{ Technical value } & \multirow{2}{*}{2.57} & \multirow{2}{*}{1.246} & $\mathrm{n}$ & 17 & 17 & 22 & 7 & 7 \\
\hline & & & & $\%$ & 24.3 & 24.3 & 31.4 & 10.0 & 10.0 \\
\hline & \multicolumn{9}{|c|}{ Cronbach's Alpha $=0.807$, Scale mean $=3.63$, Hotelling's $\mathrm{T}^{2}=162.929, \mathrm{P}=0.0001$} \\
\hline \multirow{11}{*}{ 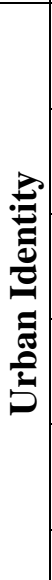 } & \multirow{2}{*}{$\begin{array}{l}\text { Its contribution to its state as a city of } \\
\text { tourism }\end{array}$} & \multirow{2}{*}{3.81} & \multirow{2}{*}{1.146} & $\mathrm{n}$ & 3 & 7 & 14 & 22 & 24 \\
\hline & & & & $\%$ & 4.3 & 10.0 & 20.0 & 31.4 & 34.3 \\
\hline & \multirow{2}{*}{$\begin{array}{l}\text { Its contribution to its state as a city of } \\
\text { culture/art }\end{array}$} & \multirow{2}{*}{3.51} & \multirow{2}{*}{1.189} & $\mathrm{n}$ & 4 & 12 & 14 & 24 & 16 \\
\hline & & & & $\%$ & 5.7 & 17.1 & 20.0 & 34.3 & 22.9 \\
\hline & \multirow{2}{*}{$\begin{array}{l}\text { Its contribution to its state as a city of } \\
\text { trade }\end{array}$} & \multirow{2}{*}{3.36} & \multirow{2}{*}{1.341} & $\mathrm{n}$ & 8 & 11 & 18 & 14 & 19 \\
\hline & & & & $\%$ & 11.4 & 15.7 & 25.7 & 20.0 & 27.1 \\
\hline & \multirow{2}{*}{$\begin{array}{l}\text { Its contribution to its state as a city of } \\
\text { rent }\end{array}$} & \multirow{2}{*}{2.04} & \multirow{2}{*}{1.173} & $\mathrm{n}$ & 30 & 18 & 16 & 1 & 5 \\
\hline & & & & $\%$ & 42.9 & 25.7 & 22.9 & 1.4 & 7.1 \\
\hline & \multirow{2}{*}{$\begin{array}{l}\text { Its contribution to its state as a historic } \\
\text { city }\end{array}$} & \multirow{2}{*}{4.24} & \multirow{2}{*}{1.042} & $\mathrm{n}$ & 2 & 4 & 7 & 19 & 38 \\
\hline & & & & $\%$ & 2.9 & 5.7 & 10.0 & 27.1 & 54.3 \\
\hline & Cronbach's Alpha $=0.567$, Scale & ean & 9 , Hote & $g$ & ${ }^{2}=146$. & $675, \mathrm{P}$ & $=0.00$ & & \\
\hline
\end{tabular}

*1-Very bad, 2-Bad, 3-Slightly good/moderate, 4-Good, 5-Very good 
Besides, as also stated by the CHVIP (Çanakkale Houses Vitalization Project)-the Historic City Commission (2016), magnificent examples of the iron grills making up the façade surfaces of the avenue can be seen together with their circular constructions, which generally develop from a single center. Designed by the then architects or journeymen and masters, these grills are still preserving their originality and rarity. As also stated by the respondents, the avenue therefore gets the third highest contribution (mean 3.73) from "originality and rarity value". Çarş1 Avenue is in some order with its attached and single-, two-, and three-storey buildings. The front façades of the buildings that sit on a linear street are directly related to the avenue. These buildings also resemble the arched shop windows. The door and window joinery of the buildings is generally wooden and was decorated with various wrought-iron railings. As also stated by the respondents, these details enhance the "aesthetic and artistic value" of the avenue and this parameter makes a significant contribution (mean 3.50) to the formation of the spatial memory in the fourth degree (Table 1).

Located in the upper section of the avenue, "Aynal1 (Mirrored) Bazaar" has been the subject of songs, poems, and books since the period of its construction. It is one of the spaces that come to mind first when Çanakkale is considered and that the tourists coming to the city want to see the most. The studies for the conservation of the historical pattern in the place concerned also contribute to the tourism in the city. Furthermore, this avenue, one of the places with the maximum opportunities for shopping, enlivens both tourism and trade. In this context, as also stated by the respondents (mean 4.24-3.81), the avenue contributes to the state of the city as "a city of history and tourism" (Table 1).

When Çarşı Avenue is evaluated in terms of the urban images, it is seen that the highest rate belongs to the image of "path" $(50.0 \%)$ because the intensive commercial function of the avenue, its uninterrupted continuation along a line, the fact that it is distinguished from the other streets by its pavement and ground flooring and the continuation of its façade pattern along the path strengthen the image of "path". The respondents secondly indicated the avenue as a "node" (45.7\%). The presence of banks, various shops, and cafés at the avenue concerned contributed to its being a "node". Also identified as a district (31.4\%), this space is at the same time expressed as a "district" which has the maximum opportunities for shopping and which is distinguished from the other avenues and streets by this aspect (Table 2).

Table 2. The distribution of selection of the urban image for Çarşı Avenue

\begin{tabular}{|l|c|c|}
\hline Urban Image & Respondents & Percentage \\
\hline Paths & 35 & 50.0 \\
\hline Edges & 18 & 25.7 \\
\hline Districts & 22 & 31.4 \\
\hline Nodes & 32 & 45.7 \\
\hline Landmarks & 19 & 27.1 \\
\hline
\end{tabular}

\subsection{Fetvane Street}

With its street pattern, which preserves its historical integrity today as well, Fetvane Street makes more contributions to the formation of the spatial memory in the context of the parameter of "historical and cultural value" (mean 4.56). Besides, Fetvane Street also has a high contribution (mean 4.26) to the parameter of "memory value and continuity of use" as it was formed in the years when the city was established and as it is still used intensively. This narrow street, whose traditional architecture has been preserved, is in integrity with its unique building style and material pattern. The abundance of registered buildings draws attention on the street, where the traditional street pattern has also been preserved. Even though these buildings have 
changed their previous functions, they significantly contribute to the unique structure of the street. As also stated by the respondents, Fetvane Street, one of the rare streets in the city with its building characters and street pattern, contributes to the formation of the spatial memory in the second degree (mean 3.97) in the context of the parameter of "originality and rarity value". Fetvane Street is a street which is located between the Clock Tower and the Yalı Mosque as a blend of the Modern Age and the Ottoman Period and to which the buildings used as shops, hotels, waterside mansions, and houses add "artistic value". The buildings with a façade on Fetvane Street are single- two- or three-storey attached historic buildings. The two-storey masonry buildings on the street coexist with their different colors and patterns. The buildings were generally made from stone materials. The solids and voids created on the façades at similar rates provide façade integrity. The cobblestone pavement of Fetvane Street also adds "aesthetic value" to the street. Although those buildings which are used after they have been restored and altered on this historic street, where one can see the previous construction techniques and material pattern, constitute the majority, it is seen that they still preserve their aesthetic appearances. Thus, the parameter of "aesthetic and artistic value" makes a significant contribution (mean 3.84) to the formation of the spatial memory in the third degree (Table 3 ).

When Fetvane Street was first formed, it drew attention with its such buildings as depots and restaurants, the majority of which belonged to Greeks, as well as with its proximity to the harbor. In time, the shops were monopolized by Muslim families also upon the emigration of the Greek people. Housing many registered buildings, this street was formed in the processes following the early years of the establishment of the city and also contributed to the city's acquisition of a "historical" identity (mean 4.33). Considered to make a substantial (mean 4.21) contribution to the "cultural/artistic identity" of the city as well, this street mostly hosts various cultural/artistic activities. The bookshops where famous writers and poets come, Yalı Khan, where different groups (e.g. CHVIP-Historic City Commission, Local Agenda 21 of Çanakkale, and the City Council of Çanakkale) assemble and organize meetings and the cafés and bars where various musical activities take place are examples of this. This street, the use of which has been continuing to date, has acquired a place in the memory of the respondents with the bookshops lined up along both sides of the street besides its cafés and bars, which predominantly serve the entertainment sector. Located on the street as one of the important spaces, Yal1 Khan has become an important symbol of the street for the city dwellers and for those who come from outside. Involving the cultural, artistic, and entertainment activities, Fetvane Street also makes a significant contribution to the city's acquisition of a "touristic" identity (mean 3.90) with all these characteristics of its (Table 3). 
Table 3. Reliability of the scales (spatial memory/urban identity) for Fetvane Street and their mean values

\begin{tabular}{|c|c|c|c|c|c|c|c|c|c|}
\hline & Spatial Memory Parameters & Mean & $\begin{array}{c}\text { Std. } \\
\text { Deviation }\end{array}$ & & $1 *$ & $2 *$ & $3 *$ & $4 *$ & $5^{*}$ \\
\hline & \multirow{2}{*}{ Historical and cultural value } & \multirow{2}{*}{4.56} & \multirow{2}{*}{.651} & $\mathrm{n}$ & & & 6 & 19 & 45 \\
\hline & & & & $\%$ & & & 8.6 & 27.1 & 64.3 \\
\hline & \multirow{2}{*}{ Originality and rarity value } & \multirow{2}{*}{3.97} & \multirow{2}{*}{.851} & $\mathrm{n}$ & & 3 & 17 & 29 & 21 \\
\hline 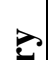 & & & & $\%$ & & 4.3 & 24.3 & 41.4 & 30.0 \\
\hline : & \multirow{2}{*}{ Aesthetic and artistic value } & \multirow{2}{*}{3.84} & \multirow{2}{*}{.879} & $\mathrm{n}$ & & 4 & 21 & 27 & 18 \\
\hline$\sum$ & & & & $\%$ & & 5.7 & 30.0 & 38.6 & 25.7 \\
\hline : & \multirow{2}{*}{ Memory value and continuity of use } & \multirow{2}{*}{4.26} & \multirow{2}{*}{.811} & $\mathrm{n}$ & & 2 & 10 & 26 & 32 \\
\hline के & & & & $\%$ & & 2.9 & 14.3 & 37.1 & 45.7 \\
\hline & \multirow{2}{*}{ Technical value } & \multirow{2}{*}{2.46} & \multirow{2}{*}{1.236} & $\mathrm{n}$ & 19 & 19 & 19 & 7 & 6 \\
\hline & & & & $\%$ & 27.1 & 27.1 & 27.1 & 10.0 & 8.6 \\
\hline & \multicolumn{9}{|c|}{ Cronbach's Alpha $=0.707$, Scale mean $=3.817$, Hotelling's $T^{2}=191.7, P=0.0001$} \\
\hline & \multirow{2}{*}{$\begin{array}{l}\text { Its contribution to its state as a city of } \\
\text { tourism }\end{array}$} & \multirow{2}{*}{3.90} & \multirow{2}{*}{1.144} & $\mathrm{n}$ & 3 & 6 & 13 & 21 & 27 \\
\hline & & & & $\%$ & 4.3 & 8.6 & 18.6 & 30.0 & 38.6 \\
\hline & \multirow{2}{*}{$\begin{array}{l}\text { Its contribution to its state as a city of } \\
\text { culture/art }\end{array}$} & \multirow{2}{*}{4.21} & \multirow{2}{*}{1.048} & $\mathrm{n}$ & & 8 & 8 & 15 & 39 \\
\hline & & & & $\%$ & & 11.4 & 11.4 & 21.4 & 55.7 \\
\hline \multirow{3}{*}{ בُ } & \multirow{2}{*}{$\begin{array}{l}\text { Its contribution to its state as a city of } \\
\text { trade }\end{array}$} & \multirow{2}{*}{3.24} & \multirow{2}{*}{1.388} & $\mathrm{n}$ & 9 & 14 & 17 & 11 & 19 \\
\hline 胥 & & & & $\%$ & 12.9 & 20.0 & 24.3 & 15.7 & 27.1 \\
\hline క్ & \multirow{2}{*}{$\begin{array}{l}\text { Its contribution to its state as a city of } \\
\text { rent }\end{array}$} & \multirow{2}{*}{2.11} & \multirow{2}{*}{1.123} & $\mathrm{n}$ & 26 & 21 & 15 & 5 & 3 \\
\hline & & & & $\%$ & 37.1 & 30.0 & 21.4 & 7.1 & 4.3 \\
\hline & \multirow{2}{*}{$\begin{array}{l}\text { Its contribution to its state as a } \\
\text { historic city }\end{array}$} & \multirow{2}{*}{4.33} & 050 & $\mathrm{n}$ & 1 & 3 & 9 & 16 & 41 \\
\hline & & & .959 & $\%$ & 1.4 & 4.3 & 12.9 & 22.9 & 58.6 \\
\hline
\end{tabular}

*1-Very bad, 2-Bad, 3-Slightly good/moderate, 4-Good, 5-Very good

When Fetvane Street is evaluated in terms of the urban images, it is seen that it corresponds to the image of "path" with the largest percentage (52.9\%). Besides, it was called a "district"

$(34.3 \%)$ by the respondents due to the high density of traditional buildings (Table 4). Moreover, the important historic buildings on the street also enable the street to be perceived as a "node" (42.9\%) (Table 4).

Table 4. The distribution of selection of the urban image for Fetvane Street

\begin{tabular}{|l|c|c|}
\hline Urban Image & Respondents & Percentage \\
\hline Paths & 37 & 52.9 \\
\hline Edges & 18 & 25.7 \\
\hline Districts & 24 & 34.3 \\
\hline Nodes & 30 & 42.9 \\
\hline Landmarks & 22 & 31.4 \\
\hline
\end{tabular}




\subsection{Zafer Square}

In the memories of the respondents, Zafer Square is perceived together with its historic buildings with original qualities, which are located on its periphery and which date back to very ancient times. Therefore, Zafer Square makes more contributions to the formation of the spatial memory in terms of the parameters of "historical and cultural value" (mean 4.56) and "originality and rarity value" (mean 4.23) (Table 5). Even though the space has failed to acquire a place in the memory of the city dwellers as "Zafer Square", it contributes to the city's acquisition of a "historical" identity at a high rate (mean 4.20) with all these characteristics of its and as "the Old Church Square" (Table 5).

Table 5. Reliability of the scales (spatial memory/urban identity) for Zafer Square and their mean values

\begin{tabular}{|c|c|c|c|c|c|c|c|c|c|}
\hline & Spatial Memory Parameters & Mean & \begin{tabular}{|c|} 
Std. \\
Deviation
\end{tabular} & & $1 *$ & $2 *$ & $3 *$ & $4^{*}$ & $5^{*}$ \\
\hline \multirow{2}{*}{\multicolumn{2}{|c|}{ Historical and cultural value }} & \multirow{2}{*}{4.56} & \multirow{2}{*}{.715} & $\mathrm{n}$ & & 2 & 3 & 19 & 46 \\
\hline & & & & $\%$ & & 2.9 & 4.3 & 27.1 & 65.7 \\
\hline \multirow{6}{*}{ 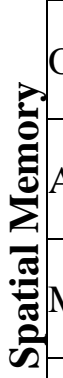 } & \multirow{2}{*}{ Originality and rarity value } & \multirow{2}{*}{4.23} & \multirow{2}{*}{.935} & $\mathrm{n}$ & 2 & 1 & 9 & 25 & 33 \\
\hline & & & & $\%$ & 2.9 & 1.4 & 12.9 & 35.9 & 47.1 \\
\hline & \multirow{2}{*}{ Aesthetic and artistic value } & \multirow{2}{*}{3.87} & \multirow{2}{*}{1.089} & $\mathrm{n}$ & 2 & 7 & 13 & 24 & 24 \\
\hline & & & & $\%$ & 2.9 & 10.0 & 18.6 & 34.3 & 34.3 \\
\hline & \multirow{2}{*}{ Memory value and continuity of use } & \multirow{2}{*}{3.30} & \multirow{2}{*}{1.267} & $\mathrm{n}$ & 8 & 11 & 16 & 22 & 13 \\
\hline & & & & $\%$ & 11.4 & 15.7 & 22.9 & 31.4 & 18.6 \\
\hline & \multirow{2}{*}{ Technical value } & \multirow{2}{*}{2.31} & \multirow{2}{*}{1.246} & $\mathrm{n}$ & 24 & 17 & 17 & 7 & 5 \\
\hline & & & & $\%$ & 34.3 & 24.3 & 24.3 & 10.0 & 7.1 \\
\hline
\end{tabular}

Cronbach's Alpha $=0.727$, Scale mean $=3.654$, Hotelling's $\mathrm{T}^{2}=229.256, \mathrm{P}=0.0001$

\begin{tabular}{|c|c|c|c|c|c|c|c|c|}
\hline \multirow{2}{*}{$\begin{array}{l}\text { Its contribution to its state as a city of } \\
\text { tourism }\end{array}$} & \multirow{2}{*}{2.99} & \multirow[b]{2}{*}{1.479} & $\mathrm{n}$ & 15 & 14 & 15 & 9 & 17 \\
\hline & & & $\%$ & 21.4 & 20.0 & 21.4 & 12.9 & 24.3 \\
\hline \multirow{2}{*}{$\begin{array}{l}\text { Its contribution to its state as a city of } \\
\text { culture/art }\end{array}$} & \multirow{2}{*}{3.80} & \multirow[b]{2}{*}{1.258} & $\mathrm{n}$ & 6 & 6 & 9 & 24 & 25 \\
\hline & & & $\%$ & 8.6 & 8.6 & 12.9 & 34.3 & 35.7 \\
\hline \multirow{2}{*}{$\begin{array}{l}\text { Its contribution to its state as a city of } \\
\text { trade }\end{array}$} & \multirow{2}{*}{1.84} & \multirow[b]{2}{*}{1.044} & $\mathrm{n}$ & 33 & 23 & 9 & 2 & 3 \\
\hline & & & $\%$ & 47.1 & 32.9 & 12.9 & 2.9 & 4.3 \\
\hline \multirow{2}{*}{$\begin{array}{l}\text { Its contribution to its state as a city of } \\
\text { rent }\end{array}$} & \multirow{2}{*}{1.61} & \multirow[b]{2}{*}{.889} & $\mathrm{n}$ & 40 & 21 & 7 & & 2 \\
\hline & & & $\%$ & 57.1 & 30.0 & 10.0 & & 2.9 \\
\hline \multirow{2}{*}{$\begin{array}{l}\text { Its contribution to its state as a historic } \\
\text { city }\end{array}$} & \multirow{2}{*}{4.20} & \multirow[b]{2}{*}{.987} & $\mathrm{n}$ & 1 & 3 & 13 & 17 & 36 \\
\hline & & & $\%$ & 1.4 & 4.3 & 18.6 & 24.3 & 51.4 \\
\hline
\end{tabular}

*1-Very bad, 2-Bad, 3-Slightly good/moderate, 4-Good, 5-Very good

When Zafer Square is evaluated in terms of the urban images, it is seen that especially the Armenian Church, the Tiflı Mosque and the Korfmann Library cause the square to be identified as both a separate "district" and a "node" owing to the presence of each building. The presence of the mosque and the church at the same square also contributes to cultural diversity. Besides, the respondents thinking that the square is merely used as a crossing route think that regulations supporting the historic structure should be made for the square. The Armenian 
Church has acquired a place in the memory as the most important building of the square; however, it has frequently undergone adaptive reuse, which weakens its place in the memories of both the city dwellers and the city (Table 6).

Table 6. The distribution of selection of the urban image for Zafer Square

\begin{tabular}{|l|c|c|}
\hline Urban Image & Respondents & Percentage \\
\hline Paths & 14 & 20.0 \\
\hline Edges & 11 & 15.7 \\
\hline Districts & 35 & 50.0 \\
\hline Nodes & 42 & 60.0 \\
\hline Landmarks & 28 & 40.0 \\
\hline
\end{tabular}

\subsection{The Public Garden}

With the quality of being one of the oldest open-green areas in the city, the Public Garden makes more contributions to the formation of the spatial memory in the context of the parameter of "memory value and continuity of use" (mean 4.09). Formed after the Calvert Family had organized the backyard of their own house and stated to have been established on a much wider area, the Public Garden is also of historical importance for the city. Thus, the parameter of "historical and cultural value" also has a high rate (mean 3.64). Generally used as a space for crossing by the respondents, the garden remains among the Governor's Office Building, the Old State Hospital, the Municipality Office Building, and partially the City Stadium. This urban space, which has been used since its formation, is also used alternately as an exhibition and festival area from time to time. The "originality and rarity value" (mean 3.63) of this garden, which has acquired a place as a green area in the memories of the respondents, was also found high. The respondents also stated that they thought that this space should be used more productively. It is also particularly stressed that this garden, which is also used as a meeting point, does not serve the purpose of recreation - the most fundamental feature that an open-green area should possess - much (Table 7).

Most of the respondents stating that the Public Garden hardly contributes to the urban identity express that the space makes more contributions to the state of the city as "a city of culture/art" in the context of some cultural-artistic activities carried out in the garden (Table 7). 
Table 7. Reliability of the scales (spatial memory/urban identity) for the Public Garden and their mean values

\begin{tabular}{|c|c|c|c|c|c|c|c|c|c|}
\hline & Spatial Memory Parameters & Mean & $\begin{array}{c}\text { Std. } \\
\text { Deviation }\end{array}$ & & $1 *$ & $2 *$ & $3^{*}$ & $4^{*}$ & $5^{*}$ \\
\hline & \multirow{2}{*}{ Historical and cultural value } & \multirow{2}{*}{3.64} & \multirow{2}{*}{1.240} & $\mathrm{n}$ & 6 & 5 & 19 & 18 & 22 \\
\hline & & & & $\%$ & 8.6 & 7.1 & 27.1 & 25.1 & 31.4 \\
\hline \multirow{8}{*}{ 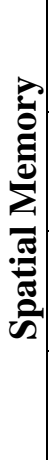 } & \multirow{2}{*}{ Originality and rarity value } & \multirow{2}{*}{3.63} & \multirow{2}{*}{1.182} & $\mathrm{n}$ & 4 & 7 & 21 & 17 & 21 \\
\hline & & & & $\%$ & 5.7 & 10.0 & 30.0 & 24.3 & 30.0 \\
\hline & \multirow{2}{*}{ Aesthetic and artistic value } & \multirow{2}{*}{3.30} & \multirow{2}{*}{1.172} & $\mathrm{n}$ & 5 & 12 & 23 & 17 & 13 \\
\hline & & & & $\%$ & 7.1 & 17.1 & 32.9 & 24.3 & 18.6 \\
\hline & \multirow{2}{*}{ Memory value and continuity of use } & \multirow{2}{*}{4.09} & \multirow{2}{*}{1.004} & $\mathrm{n}$ & 2 & 3 & 11 & 25 & 29 \\
\hline & & & & $\%$ & 2.9 & 4.3 & 15.7 & 35.7 & 41.4 \\
\hline & \multirow{2}{*}{ Technical value } & \multirow{2}{*}{2.20} & \multirow{2}{*}{1.137} & $\mathrm{n}$ & 22 & 25 & 14 & 5 & 4 \\
\hline & & & & $\%$ & 31.4 & 35.7 & 20.0 & 7.1 & 5.7 \\
\hline
\end{tabular}

Cronbach's Alpha $=0.728$, Scale mean $=3.371$, Hotelling's $T^{2}=157.638, \mathrm{P}=0.0001$

\begin{tabular}{|c|c|c|c|c|c|c|c|c|c|}
\hline \multirow{2}{*}{\multicolumn{2}{|c|}{$\begin{array}{l}\text { Its contribution to its state as a city of } \\
\text { tourism }\end{array}$}} & \multirow{2}{*}{3.04} & \multirow{2}{*}{1.469} & $\pi$ & 14 & 14 & 14 & 11 & 17 \\
\hline & & & & $\%$ & 20.0 & 20.0 & 20.0 & 15.7 & 24.3 \\
\hline \multirow{8}{*}{ 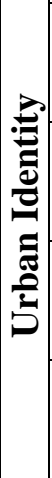 } & \multirow{2}{*}{$\begin{array}{l}\text { Its contribution to its state as a city of } \\
\text { culture/art }\end{array}$} & \multirow{2}{*}{3.46} & \multirow{2}{*}{1.369} & & 7 & 13 & 13 & 15 & 22 \\
\hline & & & & $\%$ & 10.0 & 18.6 & 18.6 & 21.4 & 31.4 \\
\hline & \multirow{2}{*}{$\begin{array}{l}\text { Its contribution to its state as a city of } \\
\text { trade }\end{array}$} & \multirow{2}{*}{2.00} & \multirow{2}{*}{1.204} & $n$ & 32 & 18 & 14 & 6 & \\
\hline & & & & $\%$ & 45.7 & 25.7 & 20.0 & 8.6 & \\
\hline & \multirow{2}{*}{$\begin{array}{l}\text { Its contribution to its state as a city of } \\
\text { rent }\end{array}$} & \multirow{2}{*}{1.69} & \multirow{2}{*}{1.057} & $\mathrm{n}$ & 43 & 13 & 10 & 1 & 3 \\
\hline & & & & $\%$ & 61.4 & 18.6 & 14.3 & 1.4 & 4.3 \\
\hline & \multirow{2}{*}{$\begin{array}{l}\text { Its contribution to its state as a } \\
\text { historic city }\end{array}$} & \multirow{2}{*}{3.20} & \multirow{2}{*}{1.314} & $\mathrm{n}$ & 8 & 14 & 20 & 12 & 16 \\
\hline & & & & $\%$ & 11.4 & 20.0 & 28.6 & 17.1 & 22.9 \\
\hline
\end{tabular}

Cronbach's Alpha $=0.681$, Scale mean $=2.68$, Hotelling's $\mathrm{T}^{2}=112.608, \mathrm{P}=0.0001$

*1-Very bad, 2-Bad, 3-Slightly good/moderate, 4-Good, 5-Very good

When the Public Garden was evaluated in terms of the urban images, it was identified as a "district" at a high rate $(71.4 \%)$ by the respondents because the boundaries of the garden are specific and sharp. The green pattern of the garden forms a border with the concrete pattern of the city. The identification of this area mostly as a meeting point by the respondents and the different form of the area from that of the city in general also strengthen its perception as a "node" $(50.0 \%)$ at a high rate (Table 8$)$.

Table 8. The distribution of selection of the urban image for the Public Garden

\begin{tabular}{|l|c|c|}
\hline Urban Image & Respondents & Percentage \\
\hline Paths & 21 & 30.0 \\
\hline Edges & 11 & 15.7 \\
\hline Districts & 50 & 71.4 \\
\hline Nodes & 35 & 50.0 \\
\hline Landmarks & 20 & 28.6 \\
\hline
\end{tabular}




\subsection{Yalı Khan}

Maintaining its use since 1889, Yalı Khan makes more contributions to the formation of the spatial memory in the context of the parameter of "historical and cultural value" (mean 4.60). The parameter of "memory value and continuity of use" (mean 4.34) has the second highest average. Yalı Khan is a space which has been used since the first day when it was constructed. The space hosts the memories of those people who were in the khan for accommodation purposes in the past as well as mostly the city dwellers, university students, and many visitors who come from outside today. One gate of Yalı Khan leads to Fetvane Street and one gate of it to Yalı Avenue. While this facilitates the access of the city dwellers to the space, the khan is also called 'yolgeçen hanı' (a place where many people are always coming and going) owing to this feature of its. Besides, it is also identified as an area for crossing and a shopping arcade (Table 9).

Table 9. Reliability of the scales (spatial memory/urban identity) for Yalı Khan and their mean values

\begin{tabular}{|c|c|c|c|c|c|c|c|c|c|}
\hline & Spatial Memory Parameters & Mean & $\begin{array}{c}\text { Std. } \\
\text { Deviation }\end{array}$ & & $1 *$ & $2 *$ & $3^{*}$ & $4^{*}$ & $5^{*}$ \\
\hline & \multirow{2}{*}{ Historical and cultural value } & \multirow{2}{*}{4.60} & \multirow{2}{*}{.730} & $\mathrm{n}$ & 1 & & 4 & 16 & 49 \\
\hline & & & & $\%$ & 1.4 & & 5.7 & 22.9 & 70.0 \\
\hline & \multirow{2}{*}{ Originality and rarity value } & \multirow{2}{*}{4.31} & \multirow{2}{*}{.877} & 11 & & 3 & 10 & 19 & 38 \\
\hline \multirow{8}{*}{ 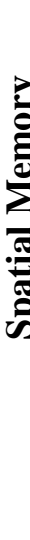 } & & & & $\%$ & & 4.3 & 14.3 & 27.1 & 54.3 \\
\hline & \multirow{2}{*}{ Aesthetic and artistic value } & \multirow{2}{*}{4.13} & \multirow{2}{*}{.900} & $\mathrm{n}$ & 2 & 1 & 9 & 32 & 26 \\
\hline & & & & $\%$ & 2.9 & 1.4 & 12.9 & 45.7 & 37.1 \\
\hline & \multirow{2}{*}{ Memory value and continuity of use } & \multirow{2}{*}{4.34} & \multirow{2}{*}{1.006} & $\mathrm{n}$ & 2 & 3 & 6 & 17 & 42 \\
\hline & & & & $\%$ & 2.9 & 4.3 & 8.6 & 24.3 & 60.0 \\
\hline & \multirow{2}{*}{ Technical } & \multirow{2}{*}{2.40} & \multirow{2}{*}{1.172} & $\mathrm{n}$ & 19 & 20 & 19 & 8 & 4 \\
\hline & & & & $\%$ & 27.1 & 28.6 & 27.1 & 11.4 & 5.7 \\
\hline & \multicolumn{9}{|c|}{ Cronbach's Alpha $=0.751$, Scale mean $=3.397$, Hotelling's $T^{2}=252.067, P=0.0001$} \\
\hline & \multirow{2}{*}{$\begin{array}{l}\text { Its contribution to its state as a city } \\
\text { of tourism }\end{array}$} & \multirow{2}{*}{3.97} & \multirow{2}{*}{1.274} & $\mathrm{n}$ & 4 & 8 & 9 & 14 & 35 \\
\hline & & & & $\%$ & 5.7 & 11.4 & 12.9 & 20.0 & 50.0 \\
\hline \multirow{6}{*}{ 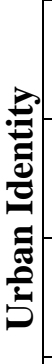 } & \multirow{2}{*}{$\begin{array}{l}\text { Its contribution to its state as a city } \\
\text { of culture/art }\end{array}$} & \multirow{2}{*}{4.24} & \multirow{2}{*}{1.096} & $\mathrm{n}$ & 3 & 4 & 5 & 19 & 39 \\
\hline & & & & $\%$ & 4.3 & 5.7 & 7.1 & 27.1 & 55.7 \\
\hline & \multirow{2}{*}{$\begin{array}{l}\text { Its contribution to its state as a city } \\
\text { of trade }\end{array}$} & \multirow{2}{*}{3.20} & \multirow{2}{*}{1.292} & $\mathrm{n}$ & 9 & 11 & 21 & 15 & 14 \\
\hline & & & & $\%$ & 12.9 & 15.7 & 30.0 & 21.4 & 20.0 \\
\hline & \multirow{2}{*}{$\begin{array}{l}\text { Its contribution to its state as a city } \\
\text { of rent }\end{array}$} & \multirow{2}{*}{1.94} & \multirow{2}{*}{1.102} & $\mathrm{n}$ & 33 & 18 & 10 & 8 & 1 \\
\hline & & & & $\%$ & 47.1 & 25.7 & 14.3 & 11.4 & 1.4 \\
\hline & \multirow{2}{*}{$\begin{array}{l}\text { Its contribution to its state as a } \\
\text { historic city }\end{array}$} & \multirow{2}{*}{4.19} & \multirow{2}{*}{1.183} & $\mathrm{n}$ & 3 & 5 & 10 & 10 & 42 \\
\hline & & & & $\%$ & 4.3 & 7.1 & 14.3 & 14.3 & 60.0 \\
\hline
\end{tabular}

*1-Very bad, 2-Bad, 3-Slightly good/moderate, 4-Good, 5-Very good

By possessing an inner courtyard and with its potential of being private, the space concerned has the qualities of both being a strong urban fragment and being distinguished from the dynamic part of the city. Thus, some respondents stated that they did not use the space 
much, whereas some others stated that they socialized in this area, which was protected from extrinsic effects. Yalı Khan and its courtyard go on protecting themselves as being isolated from the extrinsic factors behind stone walls today as well. The khan preserves its originality with its structure concerned and its rarity as it is the only khan in the city. Therefore, it is observed that the space concerned also makes great contributions to the formation of the spatial memory in the context of the parameter of "originality and rarity value" (mean 4.31) (Table 9).

This historic khan, one of the most important haunts on Fetvane Street, is essential as a space for assembling and socialization where handicraft workshops and cafés are available today, as also stated by the respondents. When identifying the khan, the respondents predominantly drew attention to the wisteria in its garden and underlined that it was a space for relaxing and sitting for the city dwellers. Additionally, it is a space where different cultural and artistic activities are performed and where different social groups can coexist. Thus, it contributes to the "cultural/artistic identity" of the city with the highest average (mean 4.24) (Table 9).

When Yal1 Khan is evaluated in terms of the urban images, it is identified as a "node" at the highest rate $(62.9 \%)$ (Table 10). One of the reasons for this is that it is located on Fetvane Street - one of the busiest streets of the city. The other one is its natural stone walls, ground flooring, and different architectural form.

Table 10. The distribution of selection of the urban image for Yalı Khan

\begin{tabular}{|l|c|c|}
\hline Urban Image & Respondents & Percentage \\
\hline Paths & 13 & 18.6 \\
\hline Edges & 17 & 24.3 \\
\hline Districts & 18 & 25.7 \\
\hline Nodes & 44 & 62.9 \\
\hline Landmarks & 31 & 44.3 \\
\hline
\end{tabular}

\subsection{The Yalı Mosque}

The Yalı Mosque makes more contributions to the formation of the spatial memory in the context of the parameter of "historical and cultural value" (mean 4.59) as it is one of the oldest worshipping buildings of the city and with its striking historical pattern. Even though the use of the Yalı Mosque was restricted for a short time due to the fires it suffered from in different periods, the continuity of its use has been taking place since the date of its construction. At the same time, it is one of the important religious spaces which have witnessed the important events in the city. Thus, the parameter of "memory value and continuity of use" has the second highest average (mean 4.26) (Table 11).

In their views, the respondents particularly emphasized the original architectural form of its minaret. The traditional stone material used in the construction of the mosque substantially distinguishes the building from the other mosques. For these reasons, the average of "originality and rarity value" of the Yalı Mosque (mean 4.03) was also found high in the context of the spatial memory parameters (Table 11).

The Yalı Mosque is within the early establishment core of the city; furthermore, its garden houses both the muvakkithane building and tombs. In this respect, the building concerned contributes to the "historic city" identity of the city with a high average (mean 4.39) (Table 11). 
Table 11. Reliability of the scales (spatial memory/urban identity) for Yalı Mosque and their mean values

\begin{tabular}{|c|c|c|c|c|c|c|c|c|c|}
\hline & Spatial Memory Parameters & Mean & \begin{tabular}{c|} 
Std. \\
Deviation
\end{tabular} & & $1 *$ & $2 *$ & $3 *$ & $4^{*}$ & $5^{*}$ \\
\hline & \multirow{2}{*}{ Historical and cultural value } & \multirow{2}{*}{4.59} & \multirow{2}{*}{.670} & $\mathrm{n}$ & & & 7 & 15 & 48 \\
\hline & & & & $\%$ & & & 10.0 & 21.4 & 68.6 \\
\hline & \multirow{2}{*}{ Originality and rarity value } & \multirow{2}{*}{4.03} & \multirow{2}{*}{.916} & $\mathrm{n}$ & & 4 & 16 & 24 & 26 \\
\hline 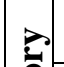 & & & & $\%$ & & 5.7 & 22.9 & 34.3 & 37.1 \\
\hline 章 & \multirow{2}{*}{ Aesthetic and artistic value } & \multirow{2}{*}{3.99} & \multirow{2}{*}{.909} & $\mathrm{n}$ & & 2 & 23 & 19 & 26 \\
\hline$\sum_{\Sigma}$ & & & & $\%$ & & 2.9 & 32.9 & 27.1 & 37.1 \\
\hline \multirow{3}{*}{ 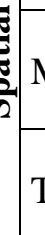 } & \multirow{2}{*}{ Memory value and continuity of use } & \multirow{2}{*}{4.26} & \multirow{2}{*}{.846} & $\mathrm{n}$ & & 2 & 12 & 22 & 34 \\
\hline & & & & $\%$ & & 2.9 & 17.1 & 31.4 & 48.6 \\
\hline & \multirow{2}{*}{ Technical value } & \multirow{2}{*}{2.39} & \multirow{2}{*}{1.231} & $\mathrm{n}$ & 21 & 19 & 17 & 8 & 5 \\
\hline & & & & $\%$ & 30.0 & 27.1 & 24.3 & 11.4 & 7.1 \\
\hline & \multicolumn{9}{|c|}{ Cronbach's Alpha $=0.823$, Scale mean $=3.849$, Hotelling's $T^{2}=225.417, P=0.0001$} \\
\hline \multirow{2}{*}{\multicolumn{2}{|c|}{$\begin{array}{l}\text { Its contribution to its state as a city } \\
\text { of tourism }\end{array}$}} & \multirow{2}{*}{3.44} & \multirow{2}{*}{1.293} & $\mathrm{n}$ & 8 & 8 & 16 & 21 & 17 \\
\hline & & & & $\%$ & 11.4 & 11.4 & 22.9 & 30.0 & 24.3 \\
\hline \multirow{6}{*}{ 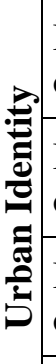 } & \multirow{2}{*}{$\begin{array}{l}\text { Its contribution to its state as a city } \\
\text { of culture/art }\end{array}$} & \multirow{2}{*}{3.63} & \multirow{2}{*}{1.374} & $\mathrm{n}$ & 8 & 8 & 11 & 18 & 25 \\
\hline & & & & $\%$ & 11.4 & 11.4 & 15.7 & 25.7 & 35.7 \\
\hline & \multirow{2}{*}{$\begin{array}{l}\text { Its contribution to its state as a city } \\
\text { of trade }\end{array}$} & \multirow{2}{*}{2.16} & \multirow{2}{*}{1.187} & $\mathrm{n}$ & 25 & 23 & 13 & 4 & 5 \\
\hline & & & & $\%$ & 35.7 & 23.9 & 18.6 & 5.7 & 7.1 \\
\hline & \multirow{2}{*}{$\begin{array}{l}\text { Its contribution to its state as a city } \\
\text { of rent }\end{array}$} & \multirow{2}{*}{1.66} & \multirow{2}{*}{.991} & $\mathrm{n}$ & 42 & 16 & 8 & 2 & 2 \\
\hline & & & & $\%$ & 60.0 & 22.9 & 11.4 & 2.9 & 2.9 \\
\hline \multirow{2}{*}{\multicolumn{2}{|c|}{$\begin{array}{l}\text { Its contribution to its state as a } \\
\text { historic city }\end{array}$}} & \multirow{2}{*}{4.39} & 052 & $\mathrm{n}$ & 1 & 1 & 14 & 8 & 46 \\
\hline & & & .952 & $\%$ & 1.4 & 1.4 & 20.0 & 11.4 & 65.7 \\
\hline
\end{tabular}

*1-Very bad, 2-Bad, 3-Slightly good/moderate, 4-Good, 5-Very good

When the Yal1 Mosque is evaluated in terms of the urban images, it is identified as a "node" $(67.1 \%)$ as it is at the intersection point of Çarş1 Avenue and Fetvane Street and as it is located at one of the most important avenues of the city (Table 12). Besides, the respondents also stated that the mosque had a striking color and that they therefore preferred this historic building as a meeting point.

Table 12. The distribution of selection of the urban image for Yalı Mosque

\begin{tabular}{|l|c|c|}
\hline Urban Image & Respondents & Percentage \\
\hline Paths & 16 & 22.9 \\
\hline Edges & 16 & 22.9 \\
\hline Districts & 21 & 30.0 \\
\hline Nodes & 47 & 67.1 \\
\hline Landmarks & 31 & 44.3 \\
\hline
\end{tabular}




\subsection{The Stone School (A Guest House for Teachers)}

Even though the Stone School (a Guest House for Teachers) has undergone change in function, it goes on existing as "the old school building" in the memory of the city dwellers. Thus, the Stone School makes more contributions to the formation of the spatial memory in the context of the parameter of "historical and cultural value" (mean 4.20). Since the use of the building, which had earlier been used as a school building, is continuing today as well due to a change in function, it also has a high average (mean 3.77) concerning the parameter of "memory value and continuity of use". Regarding the features of the building, its long façade, symmetrical form, inter-floor-window molding and stone material were indicated as featured by the respondents. Thus, it gets a high value (mean 3.51) from the parameter of "aesthetic and artistic value" (Table 13).

The Stone School is an important building which was constructed in the early years of the Republic. The architectural form, material and plan typology of the building show that it is an old building. Therefore, it contributes to the historical identity of the city with a high average (mean 3.73). Besides, the building concerned and its garden serve as an exhibition area and for accommodation purposes today. This contributes to both the "touristic" (mean 3.23) and "cultural/artistic" (mean 3.23) identities of the city (Table 13).

Table 13. Reliability of the scales (spatial memory/urban identity) for the Stone School and their mean values

\begin{tabular}{|c|c|c|c|c|c|c|c|c|c|}
\hline & Spatial Memory Parameters & Mean & \begin{tabular}{c|} 
Std. \\
Deviation
\end{tabular} & & $1 *$ & $2 *$ & $3 *$ & $4 *$ & $5^{*}$ \\
\hline \multirow{2}{*}{\multicolumn{2}{|c|}{ Historical and cultural value }} & \multirow{2}{*}{4.20} & \multirow{2}{*}{.844} & $\mathrm{n}$ & & 2 & 13 & 24 & 31 \\
\hline & & & & $\%$ & & 2.9 & 18.6 & 34.3 & 44.3 \\
\hline \multirow{9}{*}{ 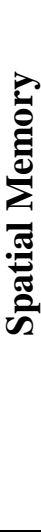 } & \multirow{2}{*}{ Originality and rarity value } & \multirow{2}{*}{3.47} & \multirow{2}{*}{1.018} & $\mathrm{n}$ & 1 & 11 & 25 & 20 & 13 \\
\hline & & & & $\%$ & 1.4 & 15.7 & 35.7 & 28.6 & 18.6 \\
\hline & & \multirow{2}{*}{3.51} & \multirow{2}{*}{.897} & $\mathrm{n}$ & & 8 & 29 & 22 & 11 \\
\hline & & & & $\%$ & & 11.4 & 41.4 & 31.4 & 15.7 \\
\hline & \multirow{2}{*}{ Memory value and continuity of use } & \multirow{2}{*}{3.77} & \multirow{2}{*}{1.024} & $\mathrm{n}$ & 2 & 6 & 16 & 28 & 18 \\
\hline & & & & $\%$ & 2.9 & 8.6 & 22.9 & 40 & 25.7 \\
\hline & \multirow{2}{*}{ Technical value } & \multirow{2}{*}{2.34} & \multirow{2}{*}{1.226} & $\mathrm{n}$ & 22 & 19 & 17 & 7 & 5 \\
\hline & & & & $\%$ & 31.4 & 27.1 & 24.3 & 10.0 & 7.1 \\
\hline & \multicolumn{9}{|c|}{ Cronbach's Alpha $=0.751$, Scale mean $=3.46$, Hotelling's $T^{2}=147.931, P=0.0001$} \\
\hline \multirow{2}{*}{\multicolumn{2}{|c|}{$\begin{array}{l}\text { Its contribution to its state as a city } \\
\text { of tourism }\end{array}$}} & \multirow{2}{*}{3.23} & \multirow{2}{*}{1.299} & $\mathrm{n}$ & 8 & 14 & 16 & 18 & 14 \\
\hline & & & & $\%$ & 11.4 & 20.0 & 22.9 & 25.7 & 20.0 \\
\hline & \multirow{2}{*}{$\begin{array}{l}\text { Its contribution to its state as a city } \\
\text { of culture/art }\end{array}$} & \multirow{2}{*}{3.23} & \multirow{2}{*}{1.353} & $\mathrm{n}$ & 10 & 13 & 12 & 21 & 14 \\
\hline$\geq$ & & & & $\%$ & 14.3 & 18.6 & 17.1 & 30.0 & 20.0 \\
\hline \multirow{6}{*}{ 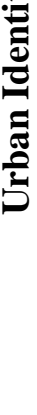 } & \multirow{2}{*}{$\begin{array}{l}\text { Its contribution to its state as a city } \\
\text { of trade }\end{array}$} & \multirow{2}{*}{2.30} & \multirow{2}{*}{1.147} & $\mathrm{n}$ & 22 & 17 & 23 & 4 & 4 \\
\hline ב & & & & $\%$ & 31.4 & 24.3 & 32.9 & 5.7 & 5.7 \\
\hline & \multirow{2}{*}{$\begin{array}{l}\text { Its contribution to its state as a city } \\
\text { of rent }\end{array}$} & \multirow{2}{*}{1.70} & \multirow{2}{*}{1.012} & $\mathrm{n}$ & 41 & 15 & 10 & 2 & 2 \\
\hline & & & & $\%$ & 58.6 & 21.4 & 14.3 & 2.9 & 2.9 \\
\hline & \multirow{2}{*}{$\begin{array}{l}\text { Its contribution to its state as a } \\
\text { historic city }\end{array}$} & \multirow{2}{*}{3.73} & \multirow{2}{*}{1.262} & $\mathrm{n}$ & 5 & 7 & 16 & 16 & 26 \\
\hline & & & & $\%$ & 7.1 & 10.0 & 22.9 & 22.9 & 37.1 \\
\hline & $=0.673$ & & 837 & i & $T^{2}=$ & 145. & $P=$ & .0001 & \\
\hline
\end{tabular}

*1-Very bad, 2-Bad, 3-Slightly good/moderate, 4-Good, 5-Very good 
When the Stone School was evaluated in terms of the urban images, it was identified as a "landmark" at a high rate (51.4\%), for the imposing appearance of the building is quite great for the street where it is located and the trees in its garden are each perceived as a landmark. Moreover, the space is also identified as a "node" (42.9\%) (Table 14) because its courtyard, which serves as a tea garden today owing to adaptive reuse, is at the same time an area for meeting/assembling and relaxing.

Table 14. The distribution of selection of the urban image for the Stone School

\begin{tabular}{|l|c|c|}
\hline Urban Image & Respondents & Percentage \\
\hline Paths & 12 & 17.1 \\
\hline Edges & 19 & 27.1 \\
\hline Districts & 21 & 30.0 \\
\hline Nodes & 30 & 42.9 \\
\hline Landmarks & 36 & 51.4 \\
\hline
\end{tabular}

\subsection{The House of Emilie Vitalis (Continuing Education Center of ÇOMU)}

The House of Emilie Vitalis, an old and important building of civil architecture in the city, makes more contributions to the formation of the spatial memory in the context of the parameter of "historical and cultural value" (mean 4.41). The building has hosted many cultures and memories also because it has frequently changed function (the Old TEKEL Building, the Old Rectorate Building, the Old Levantine Building, Attaché's Office, the Cultural House of Emilie Vitalis, the Continuing Education Center of ÇOMU, and Vitalis Café). Therefore, it also gets a high value (mean 3.63) from the parameter of "memory value and continuity of use". The two-way entrance staircase, inter-floor plaster and window molding and plaster-decorated balcony shores are striking on the external façade of the building, which is used as the Continuing Education Center of ÇOMU. It is expressed that the motifs of the wrought-iron railings of the ground floor doors and windows of the building are extremely original. Containing original qualities concerning the architectural design criteria, this building also has a high contribution in terms of the parameters of "originality and rarity value" (mean 4.13) and "aesthetic and artistic value" (mean 4.03) (Table 15).

The survival of the House of Emilie Vitalis through conservation to date contributes to the "historical" identity of the city (mean 4.09); its hosting of many cultural/artistic activities contributes to its "cultural/artistic" identity (mean 3.80); and the strategic point where it is located and the continuity of its use contribute to its "touristic" identity (mean 3.53) (Table 15). 
Table 15. Reliability of the scales (spatial memory/urban identity) for the House of Emilie Vitalis and their mean values

\begin{tabular}{|c|c|c|c|c|c|c|c|c|c|}
\hline & Spatial Memory Parameters & Mean & $\begin{array}{c}\text { Std. } \\
\text { Deviation }\end{array}$ & & $1 *$ & $2 *$ & $3 *$ & $4^{*}$ & $5^{*}$ \\
\hline & \multirow{2}{*}{ Historical and cultural value } & \multirow{2}{*}{4.41} & \multirow{2}{*}{.789} & $\mathrm{n}$ & 1 & & 7 & 23 & 39 \\
\hline & & & & $\%$ & 1.4 & & 10.0 & 32.9 & 55.7 \\
\hline & \multirow{2}{*}{ Originality and rarity value } & \multirow{2}{*}{4.13} & \multirow{2}{*}{.850} & $\mathrm{n}$ & & 3 & 12 & 28 & 27 \\
\hline & & & & $\%$ & & 4.3 & 17.1 & 40.0 & 38.6 \\
\hline & \multirow{2}{*}{ Aesthetic and artistic value } & \multirow{2}{*}{4.03} & \multirow{2}{*}{.900} & $\mathrm{n}$ & & 3 & 18 & 23 & 26 \\
\hline & & & & $\%$ & & 4.3 & 25.7 & 32.9 & 37.1 \\
\hline & \multirow{2}{*}{ Memory value and continuity of use } & \multirow{2}{*}{3.63} & \multirow{2}{*}{1.194} & $\mathrm{n}$ & 4 & 10 & 13 & 24 & 19 \\
\hline की & & & & $\%$ & 5.7 & 14.3 & 18.6 & 34.3 & 27.1 \\
\hline & \multirow{2}{*}{ Technical value } & \multirow{2}{*}{2.46} & \multirow{2}{*}{1.282} & $\mathrm{n}$ & 19 & 21 & 17 & 5 & 8 \\
\hline & & & & $\%$ & 27.1 & 30.0 & 24.3 & 7.1 & 11.4 \\
\hline & \multicolumn{9}{|c|}{ Cronbach's Alpha $=0.753$, Scale mean $=3.731$, Hotelling's $T^{2}=131.70, \mathrm{P}=0.0001$} \\
\hline & \multirow{2}{*}{$\begin{array}{l}\text { Its contribution to its state as a city } \\
\text { of tourism }\end{array}$} & \multirow{2}{*}{3.53} & \multirow{2}{*}{1.380} & $\mathrm{n}$ & 5 & 16 & 12 & 11 & 26 \\
\hline & & & & $\%$ & 7.1 & 22.9 & 17.1 & 15.7 & 37.1 \\
\hline & \multirow{2}{*}{$\begin{array}{l}\text { Its contribution to its state as a city } \\
\text { of culture/art }\end{array}$} & \multirow{2}{*}{3.80} & \multirow{2}{*}{1.281} & 11 & 5 & 9 & 8 & 21 & 27 \\
\hline & & & & $\%$ & 7.1 & 12.9 & 11.4 & 30.0 & 38.6 \\
\hline 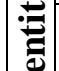 & \multirow{2}{*}{$\begin{array}{l}\text { Its contribution to its state as a city } \\
\text { of trade }\end{array}$} & \multirow{2}{*}{2.70} & \multirow{2}{*}{1.334} & $\mathrm{n}$ & 17 & 15 & 19 & 10 & 9 \\
\hline 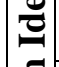 & & & & $\%$ & 24.3 & 21.4 & 27.1 & 14.3 & 12.9 \\
\hline : & \multirow{2}{*}{$\begin{array}{l}\text { Its contribution to its state as a city } \\
\text { of rent }\end{array}$} & \multirow{2}{*}{2.04} & \multirow{2}{*}{1.301} & $\mathrm{n}$ & 33 & 18 & 9 & 3 & 7 \\
\hline 5 & & & & $\%$ & 47.1 & 25.7 & 12.9 & 4.3 & 10.0 \\
\hline & \multirow{2}{*}{$\begin{array}{l}\text { Its contribution to its state as a } \\
\text { historic city }\end{array}$} & \multirow{2}{*}{4.09} & \multirow[b]{2}{*}{1.151} & $\mathrm{n}$ & 2 & 7 & 10 & 15 & 36 \\
\hline & & & & $\%$ & 2.9 & 10.0 & 14.3 & 21.4 & 51.4 \\
\hline
\end{tabular}

Cronbach's Alpha $=0.582$, Scale mean $=3.23$, Hotelling's $T^{2}=97.422, \mathrm{P}=0.0001$

*1-Very bad, 2-Bad, 3-Slightly good/moderate, 4-Good, 5-Very good

The House of Emilie Vitalis is at a valuable location thanks to its proximity to Kordon (Promenade), Quay Square, Clock Tower Square, and Çarşı Avenue. Thus, when the building is evaluated in terms of the urban images, it is identified as a "node" $(51.4 \%)$ and a "landmark" $(51.4 \%)$ at equal rates by the respondents (Table 16). Besides, its proximity to Quay Square and the easy perception of its plan diagram in different geometry strengthen its perception as a "node" and a "landmark".

Table 16. The distribution of selection of the urban image for the House of Emilie Vitalis

\begin{tabular}{|l|c|c|}
\hline Urban Image & Respondents & Percentage \\
\hline Paths & 8 & 11.4 \\
\hline Edges & 23 & 32.9 \\
\hline Districts & 22 & 31.4 \\
\hline Nodes & 36 & 51.4 \\
\hline Landmarks & 36 & 51.4 \\
\hline
\end{tabular}




\section{DISCUSSION AND CONCLUSION}

Permanent memory in space is defined as "the recording of space-related sensations, perceptions, learning, experiences, and memories in the memory during life with not only their own components but also the phenomena taking place in it, the ambient characteristics, and life, in other words, with 'its context' and their association" (Özak and Gökmen, 2009). Therefore, with all components of a city, the identity components in particular should be clear and defined.

In fact, the urban identity can be summarized as the whole of those features which distinguish a city from the others (Suher et al., 2004; Ayyıldız and Ertürk, 2017) and forms upon the gathering of many different components. The geography on which every city is established and the human community that lived/lives on it are different. Thus, as also stated by Birol (2007), the identity of a city is shaped by its cultural and natural assets. For the formation of the urban identity, the continuity of these assets should be provided and those material and immaterial assets which convey the messages coming from the past of the city to the future should be conserved. Especially the buildings and spaces which have witnessed different periods of a city join the life of city dwellers, thereby being in a privileged position among the assets concerned. Therefore, the conservation of those buildings in a city which contribute to the original identity of that city and which carry noteworthy architectural and vital features of the period they belong to plays a significant role in providing cultural continuity in that city, in the formation of the urban identity, and in carrying it to the future.

Buildings and spaces, one of the components which make up the urban identity, cast light on the human components - another component - thanks to their casting light on the social, political, cultural, and economic components of the period when they exist. The buildings and spaces of cities further become meaningful and acquire a place in the social memory with the memories of the society that has lived in that city to date. Thus, these buildings and spaces should be conserved and handed down to future generations together with their life experiences and a sustainable identity should be provided (Ayyıldız and Ertürk, 2017).

Today the identities of all cities undergo change owing to the changing requirements of the age and the expectations of the society. The most important phenomenon which preserves the cultural accumulation is the preservation of the traces of those buildings and spaces which make up the urban area in the urban memory. Unfortunately, the historical process and the cultural accumulation are not taken into consideration in the urban planning studies carried out to adapt to the changing conditions. In such studies, the identity of a city should first of all be defined accurately and planning studies which respect its past should be carried out. In this context, one of the most important studies required to be performed is to ensure that the buildings and spaces of historical value accurately acquire a place in the memory of the city dwellers. Therefore, as also stated by Taşçıoğlu and Altunkasa (2018), the urban identity elements resulting from many cultural experiences in the process that has elapsed since its establishment should be acknowledged as leading actors in the shaping of the city.

In the present study, the preservation of the places of the historic buildings and spaces in the spatial memory together with their images and its contributions to the urban identity were evaluated via the eight historic buildings and spaces selected. In this context, when the buildings and spaces which have acquired a place in the urban memory are defined in terms of spatial memory parameters and urban images, this also strengthens their contributions to the urban identity. The buildings and spaces selected as the material in the study are still being used, which strengthens the spatial memory parameters. The spatial memory parameters which affect the places of the buildings and spaces concerned in the urban identity the most are the parameters of "historical and cultural value", "memory value and continuity of use", 
"originality and rarity value", and "aesthetic and artistic value", respectively. The historic buildings and spaces identified with all these parameters contribute to the city's states as a city of "history", "culture-art", and "tourism" the most. When the buildings and spaces concerned are evaluated in terms of the urban images, they are mostly identified as "districts", "nodes", "paths", and "landmarks", which strengthens their places in the urban identity.

On the other hand, some evaluations on the buildings and spaces selected as examples were made in the section of the survey which was assessed on the basis of the quantitative observation. Selected as an avenue example, Çarşı Avenue was evaluated as a commercial and cultural core, whereas it was stated that the resulting avenue pattern was defined and guiding. This avenue at the same time has a significant place in the memories of the city and of the city dwellers with its historic buildings and spaces. These spaces are expressed as Aynalı Bazaar, the Yalı Mosque, and the City Museum. Selected as a street example, Fetvane Street was particularly addressed with its building characters as well as with the features of its use. It was stressed that the street concerned relatively reflected the original and historic urban pattern of Çanakkale. Selected as a square example, Zafer Square is identified as a whole together with the buildings of high historical value on its periphery. This demonstrates that the historic buildings maintaining their existence singly also help with the definition and perception of a public area when they are altogether. Selected as a garden example, the Public Garden is identified with the presence of wide walking tracks and a dense vegetation pattern and shows that the ways of design also influence the perception of the space. Selected as a courtyard example, Yalı Khan is mostly identified with its natural stone ground flooring-wall covering and the plant "Wisteria sinensis (wisteria)", which turns it into an attraction particularly in spring months. This also reveals the relationship of the spatial memory perception at the same time with the sensory perception. Selected as a religious space example, the Yalı Mosque was only identified as a religious building, while it was also indicated as an intersection point. The identification of the mosque with its original function emphasizes that the continuity of the function of a historic building or space strengthens its place in the spatial memory. It is expressed that the characteristic point of the Stone School, selected as a building example, is its courtyard and that this space is at the same time an area for assembling, meeting, and relaxing. It is also intensively observed that the place of this educational building, which is of extreme importance for the urban memory, in the memories of the city and of the city dwellers due to its changed function has not become clear. Finally, selected as a building section/fragment example, the House of Emilie Vitalis has had different functions to date, as the Stone School has. Besides, it is stressed that its exterior façade features are distinctive. In this context, it is understood that the architectural characteristics of a historic building or space are also of profound importance in the spatial memory perception.

Cities are not merely man-made built environments. Since cities have different spirits, they contain reflections concerning the political power, ideologies, and cultural assets of the period. In this context, avenue, street and square names have a significant place in understanding a city (Turan and Yalçıner Ercoşkun, 2017). Of the buildings and spaces selected in this context, Zafer Square, the Stone School and the House of Emilie Vitalis acquired a place in the memory of the city dwellers with different names from time to time, which also weakens the perception of the examples concerned in the spatial memory and their contribution to the urban identity.

Whilst historic buildings and spaces are integrated with the current modern urban pattern, the changes in function which do not agree with their original structure weaken the spatial perception. Functional change/adaptive reuse is an extremely appropriate practice to conserve and preserve historic patterns in the modern urbanization understanding. Nevertheless, one should avoid those functional changes which will alter or weaken the spatial 
perception as much as possible. Thus, the House of Emilie Vitalis and the Stone School do not have a very efficient place in the spatial memory of the city and in the formation of its identity owing to the functional changes they have undergone. At this point, for the accuracy and appropriateness of conservation studies, it is inevitable for property owners, city planners, architects, landscape architects, technical staff members and all other individuals working in institutions to carry out an interdisciplinary study.

It is also extremely important that all individuals living in the society be accurately trained and informed about historic assets so that the social consciousness of this matter will also be enhanced in the same line. Raising social consciousness of this matter also contributes to the formation of the urban memory. The preservation of a building or a space is possible through preserving its original assets and its acquisition of a place in the urban memory. Every building or space which has acquired a correct place in the memory also plays an efficient role in the shaping of the identity of a city. 


\section{REFERENCES}

ALGÖR, İ., 2007, Çanakkale Yalı Hanı ve Han Sakinleri, Everest Yayınlar1-İstanbul, ISBN: 975-289-409-9.

ALTUĞ TURAN, İ. and GÜLGÜN, B., 2016, Kentsel Kimlik ve Kentli İlişkisi Üzerine Bir Araştırma, Ege Üniversitesi Ziraat Fakültesi Dergisi, 53 (2), 203-211.

ASAR, H., 2013, Mimari Mekân Okumasında Algısal Deneyim Analizinin Bir Yöntem Yardımıyla İrdelenmesi, Thesis (MSc.), Eskişsehir Osmangazi University.

ASLAN, S. and KİPER, P., 2016, Kimlik ve Bellek Sorunu Sarmalında Kentler: Amasra Kenti Örneğinde Firsatlar ve Tehditlerin Değerlendirilmesi, Iddeal Kent Dergisi, 20 (7), 881905.

AYYILDIZ, S. and ERTÜRK, F., 2017, Kentsel Kimlik Bileşenleri ile Yerel Kimliğin İzlerini Sürmek: Kapanca Sokak Örneği, Mimarlık ve Yaşam Dergisi, 2 (1), 65-88.

BAŞARAN UYSAL, A., 2013, Katılımcı Senaryo Tekniği Yardımıyla Tarihi Kentsel Alan İçin İyileştirme Stratejisinin Belirlenmesi, METU JFA, 2, 137-162.

BİROL, G., 2007, Bir Kentin Kimliği ve Kervansaray Oteli Üzerine Bir Değerlendirme, Arkitekt Dergisi, 514, 46-54.

BOZDAĞ, A., 2015, Kentsel Dönüşüm Uygulamalarının Uzlaşmacı Arazi Kullanım Planlaması Açısından Analizi, Thesis (Ph.D.), Selçuk University.

BÜBERCİ, M., 2003, 19. Yüzyılda Sosyo-Ekonomik Yapı Çanakkale, Thesis (MSc.), Marmara University.

CALVINO, I., 2002, Görünmez Kentler (Çeviren: Işıl Saatçıŏlu), Yapı Kredi Yayınları, İstanbul, ISBN: 978-975-08-0466-3.

DIRECTORATE OF THE COUNCIL FOR THE CONSERVATION OF CULTURAL AND NATURAL PROPERTIES OF ÇANAKKALE (ÇKTVKK), 1996, EKTVKK'nun 14.11.1996 Gün / 2416 Sayılı Kararı ile Onaylanan Koruma Amaçlı İmar Planı Örneği, 1: 100, Çanakkale: T. C. Kültür ve Turizm Bakanlığı Çanakkale Kültür Varlıklarını Koruma Bölge Kurulu.

DIRECTORATE OF THE REGIONAL COUNCIL FOR THE CONSERVATION OF CULTURAL PROPERTIES OF ÇANAKKALE (ÇKVKBK), 2018, Çanakkale Kültür Varlıklarını Koruma Bölge Kurulu Kararları, Kültür ve Turizm İl Müdürlügüü, Çanakkale.

ÇAVUŞ, C. Z. and KOÇ, T., 2004, Çanakkale Kenti'nde Yerleşmenin Tarihçesi ve Cumhuriyet Öncesi Gelişim - Çanakkale Yerleşmesinin Durum Raporu 2003, Çanakkale Kent Konseyi Yayınları, Olay Gazetesi, Çanakkale.

CHVIP (ÇANAKKALE HOUSES VITALIZATION PROJECT)-THE HISTORIC CITY COMMISSION, 1997, Çanakkale Evleri Yaşatma Projesi (Editör: İsmail Erten), Çanakkale Belediyesi/ÇEYAP, Çanakkale, ISBN: 975-94753-0-8.

CHVIP (ÇANAKKALE HOUSES VITALIZATION PROJECT)-THE HISTORIC CITY COMMISSION, 2016, Çanakkale Yapıları Tasarım Rehberi, Çanakkale Olay Gazetesi, Çanakkale, ISBN: 975-94753-1-6.

DİKER, M. and ÇOLPAN ERKAN, N., 2017, Kent Kimliğinde İbadet Yapıları: Antakya Örneği, Planlama Dergisi, 27 (2), 180-192. 
DÜNDAR, M., 2017, Çanakkale'de Geç Osmanlı Dönemi Camileri, Çanakkale Araştırmaları Türk Ylllı̆̆, 15 (23), 61-92.

ER, N., 2014, Günlük Bellek Ölçeklerinin Geliştirilmesi: Bir Faktör Analizi Çalışması, Ankara Üniversitesi Dil ve Tarih-Coğrafya Fakültesi Dergisi, 54 (1), 191-228.

ERDÖNMEZ M. E. and AKI, A., 2005, Açık Kamusal Kent Mekanlarının Toplum İlişkilerindeki Etkileri, MEGARON YTÜ Mim. Fak. e-Dergisi, 1 (1), 67-87.

ERDURAN NEMUTLU, F., GÜNAL, İ. and KABAŞ, S., 2008, Çanakkale Halk Bahçesi Bitkisel Potansiyeli ve Alınması Gerekli Önlemler, Çanakkale İli Değerleri Seтроzуити, 25-26 Ağustos 2008, Çanakkale: Aynalı Pazar Matbaası, 201-209.

EREN, R., 1990, Çanakkale ve Yöresi Türk Devri Eserleri, Çanakkale Seramik A.Ş. Yayınları, İstanbul.

FARRELLY, L., 2011, Mimarlı̆̆ın Temelleri (Çeviren: Neslihan Şık). Literatür Yayıncılık, İstanbul, ISBN: 978-975-04-0576-1.

GÜLER, T., ŞAHNAGILL, S. and GÜLER, H., 2016, Kent Kimliğinin Oluşturulmasında Kültürel Unsurların Önemi: Balıkesir Üzerine Bir İnceleme, PARADOKS Ekonomi, Sosyoloji ve Politika Dergisi, 11, 85-104.

Güleryüz N., 2017. Çanakkale'de İki Tarihi Yapı Aynalı Çarşı ve Saat Kulesi [online], http://www.salom.com.tr/haber-103931 canakkalede_iki_tarihi_yapi__aynali_carsi_ve_saat_kulesi.html, [Date Accessed: 17 May 2018].

GÜNEROĞLU, N. and BEKAR, M., 2017, Dönüşüm ve Kimlik Kavramı: Trabzon Örneği, Kastamonu Üniversitesi Orman Fakültesi Dergisi, 17 (4), 580-593.

KAYPAK, Ş., 2010, Antakya'nın Kent Kimliği Açısından İrdelenmesi, Mustafa Kemal Üniversitesi Sosyal Bilimler Enstitüsü Dergisi, 7 (14), 373-392.

KOÇ, T., 2004. Giriş - Çanakkale Yerleşmesinin Durum Raporu 2003, Çanakkale Kent Konseyi Yayınları, Olay Gazetesi, Çanakkale.

KOÇ, T., 2006, Çanakkale'nin Kentsel Gelişimi (1462-2006) ile Fiziki Coğrafya İlişkisi / Kentsel Gelişim Alanları Çalışma Grubu (İsmail Erten, Kemal Albayrak, Seda Özkök, Özgür Sinmaz, İsmail Tümay, Ali Aygün) Raporu, Çanakkale Kent Konseyi Yayınları Kitap Dizisi, Çanakkale.

KORKMAZ, Ş., 2010, Tanzimat Sonrası Çanakkale'nin İdari ve Nüfus Yapısı, Çanakkale Araştırmaları Türk Yıllı̆̆l, 3, 108-133.

KUBAN, D., 2016, Mimarlık Kavramları, Yapı Endüstri Merkezi Yayınları, İstanbul, ISBN: 978-975-7438-09-0.

KURTMAN, N., 1991, Çanakkale Eserlerinden Örnekler, Vakıf Haftası Dergisi, 1 (8), 171 178.

TOLUN, V., 2013. Osmanlı'nın Akdeniz'e Açılan Kapısı: Çanakkale (Aşklar, Savaşlar, Kahramanlar ve Çanakkale) (Ed. Filiz ÖKTEM), Yapı Kredi yayınları, İstanbul, ISBN: 978-975-0823-98-5.

KÜRKÇÜOĞLU, E. and OCAKÇI, M., 2015, Kentsel Dokuda Mekânsal Yönelme Üzerine Bir Alg1-Davranış Çalışması: Kadıköy Çarşı Bölgesi, MEGARON Dergisi, 10 (3), 365-388.

LYNCH, K., 2014, Kent İmgesi (Çeviren: İrem Başaran), Türkiye İş Bankası Kültür Yayınları (6. Basım), İstanbul, ISBN: 978-9944-88-948-3. 
ÖNEM, B. A. and KILINÇASLAN, İ., 2005, Haliç Bölgesinde Çevre Algılama ve Kentsel Kimlik, ITÜ Mimarlı, Planlama, Tasarım Dergisi, 4 (1), 115-125.

ÖYMEN ÖZAK, N., 2008. Bellek ve Mimarlık İlişkisi Kalıcı Bellekte Mekansal Öğeler, Thesis (Ph.D.), İstanbul Technical University.

ÖYMEN ÖZAK, N. and PULAT GÖKMEN, G., 2009, Bellek ve Mekân İlişkisi Üzerine Bir Model

Önerisi, İTÜ Mimarlık, Planlama, Tasarım Dergisi, 8 (2), 145-155.

SUHER, H., OCAKÇI, M., KARABAY AYATAÇ, H. and ERTEKIN, Ö., 2004, An Indicator of Sustainable Development: Urban Identity, ITÜ A/Z, 1 (2), 26-42.

TAŞÇIOĞLU, S. and ALTUNKASA, M. F., 2018, Kilis Kentsel Sit Alanında Kullanıcı Odaklı Mekânsal Alg1 Belirlemeleri, İn̈nü Üniversitesi Sanat ve Tasarım Dergisi, 8 (18), 116.

TOMBUL, M., 2015, Çanakkale Kültür Envanteri: Arkeolojik Yerleşim Alanları ve Sanat Tarihi Yapıları, T. C. Çanakkale Valiliği Yayınları, Çanakkale, ISBN: 978-605-470163-6.

TOPÇU, K., 2011, Kent Kimliği Üzerine Bir Araştırma: Konya Örneği, Uluslararası İnsan Bilimleri Dergisi, 8 (2), 1048-1072.

TURAN, S. and YALÇINER ERCOŞKUN, Ö., 2017, Meydanlardaki İsim Değişikliklerinin Kent Belleğine Etkisi: Ankara Örneği, Süleyman Demirel Üniversitesi Mimarlık Bilimleri ve Uygulamaları Dergisi, 2 (1), 55-68.

TURGAY, O., 2013, Mekânların "Arayüz" Nitelikleri Bağlamında Gündelik Yaşantıdaki Kalıcılığı. Beykent University Journal of Science and Engineering, 6 (1), 27-46.

TURKSTAT (THE TURKISH STATISTICAL INSTITUTE), 2018. Population Data about the Central Districts of Çanakkale Province [online], https://biruni.tuik.gov.tr/medas/?kn=95\&locale=tr, [Date Accessed: 30 August 2019].

TURKEY SHAPEFILE, 2019, Türkiye ve Marmara Bölgesi Haritaları [online], http://www.turkeyshapefile.com/index.html, [Date Accessed: 24 July 2019].

URALMAN, H., 2012, Müze Halkla İlişkileri Aracılığıyla Kentlilik Bilinci Oluşturma: Çanakkale'deki Müzelerin Değerlendirilmesi, Thesis (Ph.D.), Marmara University.

UYGUN, S., 2015, Çanakkale’nin Eğitim Mirası, Eğitim Araştırmaları Birliği Yayını [online], http://www.eab.org.tr/eab/media/kitap/canakkale_egitim_mirasi.pdf, [Date Accessed: 20 June 2018].

WIRTH, L., 2002, Bir Yaşam Biçimi Olarak Kentleşme, 20.Yüzyıl Kenti (Derleme ve Çeviri: Ayten Alkan, Bülent Duru). İmge Kitabevi Yayınları, Ankara, ISBN: 978-975-533348-9.

YILDIRIM ERNIŞ, İ. I., 2012, Fiziksel Elemanların Yüzer Yapılarda Mekân Algısına Olan Etkileri: Çevre ve İnsan Davranışı İlişkisi Bağlamında İrdelenmesi, Thesis (Ph.D.), Dokuz Eylül University. 